\title{
Anti-Müllerian Hormone (AMH) and fertility management in agricultural species
}

\author{
F Mossa ${ }^{1}$, F Jimenez-Krassel ${ }^{2,+}$, D Scheetz ${ }^{2}$, M Weber-Nielsen², A C O Evans ${ }^{3}$ and J J Ireland ${ }^{2,+}$ \\ ${ }^{1}$ Department of Veterinary Medicine, University of Sassari, Sassari, Italy, ${ }^{2}$ Department of Animal Science, \\ Michigan State University, East Lansing, Michigan, USA and ${ }^{3}$ School of Agriculture and Food Science, \\ University College Dublin, Belfield, Dublin, Ireland
}

Correspondence should be addressed to F Mossa; Email: fmossa@uniss.it

${ }^{\dagger}$ (F Jimenez-Krassel and J J Ireland are now at Molecular Reproductive Endocrinology Laboratory, Michigan State University, East Lansing, Michigan, USA)

\begin{abstract}
A reliable, easy to assess marker for fertility in agricultural species would be highly desirable and Anti-Müllerian Hormone (AMH) is a promising candidate. This review summarizes recent findings concerning AMH and its role in fertility management, mainly in cattle. It focuses on (1) alterations in circulating AMH concentrations from birth to puberty and during estrous cycles; (2) correlation of circulating AMH concentrations with ovarian follicle numbers and ovarian reserve; (3) factors that impact circulating AMH concentrations; (4) use of AMH as a predictor of fertility. Circulating AMH concentrations can be easily and reliably measured with a single blood sample in adult cattle because AMH varies minimally during the estrous cycle and is repeatable across multiple cycles. Circulating AMH concentrations are positively associated with several measures of fertility. Dairy heifers with low compared with higher AMH concentrations subsequently had lower pregnancy rates, higher probability of being culled after birth of their first calf and shorter herd longevity. Also, AMH is predictive of response to superovulation in cattle and sheep. Several factors contribute to the variability in AMH concentrations among individuals; for example, beef cattle have higher AMH than dairy cattle. Nutritional imbalances, disease and endocrine disruptors during fetal life may negatively program the size of the ovarian reserve and consequently serum AMH concentrations and potential fertility in adulthood. We conclude that AMH may be a predictor of fertility and herd longevity in cattle, whereas in sheep and other farm species, the potential association between AMH and reproductive performance remains largely unexplored.

Free Italian abstract: An Italian translation of this abstract is freely available at http://www.reproduction-online.org/content/154/1/ R1/suppl/DC1.

Reproduction (2017) 154 R1-R11
\end{abstract}

\section{Introduction}

Anti-Müllerian Hormone $(\mathrm{AMH})$ is a dimeric glycoprotein and a member of the transforming growth factor $\beta$ (TGF- $\beta$ ) family of growth and differentiation factors (Cate et al. 1986). It is named after its role in male sexual differentiation because it was originally identified in rabbit male fetuses as a testicular factor distinct from testosterone that caused regression of the Müllerian ducts (Jost 1947) and was subsequently found to be produced by Sertoli cells in males (Josso et al. 1993).

More recently, it was discovered that $\mathrm{AMH}$ is also released in females and is produced exclusively by granulosa cells of healthy, growing ovarian follicles in women, cattle and sheep (Vigier et al. 1984, Takahashi et al. 1986, Bézard et al. 1987, La Marca \& Volpe 2006). AMH expression starts as soon as follicles are initially recruited (McGee \& Hsueh 2000), reaches its highest level in preantral and small antral follicles, whereas it then decreases as the selected, FSHdependent follicle progresses toward the preovulatory stage and is absent in atretic follicles. This pattern of expression was first assessed in rodents (Ueno et al. 1989) and subsequently in women (Weenen et al. 2004), cattle (Monniaux et al. 2008) and sheep (VeigaLopez et al. 2012). In the absence of AMH, follicles are recruited at a faster rate, resulting in an exhausted pool of primordial follicles at a younger age (Durlinger et al. 1999). Further, AMH inhibits FSH-stimulated follicular growth both in vivo and in vitro in mice (Durlinger et al. 2001). Thus, AMH is considered to have two main functional roles: (1) inhibition of primordial follicular growth from the primordial follicle reserve, avoiding premature exhaustion of the ovarian follicular reserve and (2) reduction in the responsiveness to $\mathrm{FSH}$ of 
preantral and small antral follicles, modulating follicular development (reviewed by Dewailly et al. (2014)).

Although its physiological effects have not been completely elucidated, $\mathrm{AMH}$ is widely employed in clinical applications in human reproductive medicine. This is because AMH is not produced by primordial or atretic follicles. Rather, it is produced exclusively by healthy growing follicles leading to detectable concentrations of $\mathrm{AMH}$ in the blood. Therefore, $\mathrm{AMH}$ concentrations are indirectly reflective of the total number of morphologically healthy ovarian follicles in ovaries, and hence, the ovarian reserve (La Marca \& Volpe 2006). Consequently, the main application for measurement of circulating $\mathrm{AMH}$ concentrations in women is prediction of the relative size of the ovarian reserve and potential response to $\mathrm{FSH}$ treatments during assisted reproductive technologies (ART). It may also be used as a marker of ovarian dysfunction, for example, in the diagnosis of premature ovarian failure, menopause and the polycystic ovarian syndrome (Dewailly et al. 2014).

In agricultural species, a reliable, cost-effective, easyto-assess marker for fertility would be highly desirable, and $\mathrm{AMH}$ is a promising candidate. This review summarizes recent findings concerning $\mathrm{AMH}$ and its role in fertility management in agricultural species, mainly in cattle. Specifically it focuses on (1) alterations in circulating $\mathrm{AMH}$ concentrations from birth to puberty and during estrous cycles; (2) correlation of circulating $\mathrm{AMH}$ concentrations with ovarian follicle numbers and the ovarian reserve; (3) factors that impact circulating $\mathrm{AMH}$ concentrations and (4) use of $\mathrm{AMH}$ as a predictor of fertility.

\section{Alterations in circulating AMH concentrations from birth to puberty and during estrous cycles}

Understanding the physiological variations in $\mathrm{AMH}$ concentrations during life is pivotal to appreciate its potential application as a biomarker for fertility in cattle and other farm species. In women, circulating $\mathrm{AMH}$ concentrations rise during infancy (from birth to three months of age), but are stable from childhood to early adulthood (Hagen et al. 2011, Kelsey et al. 2011). We conducted a study to illustrate the variations of $\mathrm{AMH}$ from birth to puberty in Holstein female calves. Results depicted in Fig. 1 show that $\mathrm{AMH}$ concentrations increase during the first 2 months of age, decrease at 5 and are stable at 8-9 months of age, around the time of first ovulation. We also described a similar pattern in beef calves. In Maine-Anjou beef heifers, plasma AMH concentrations were found to increase rapidly between 1 and 3 months of age, to remain high at 6 and to decline slowly until 12 months of age, which corresponds to the age of ovulation for this breed (Monniaux et al. 2012). These findings are supported by results from

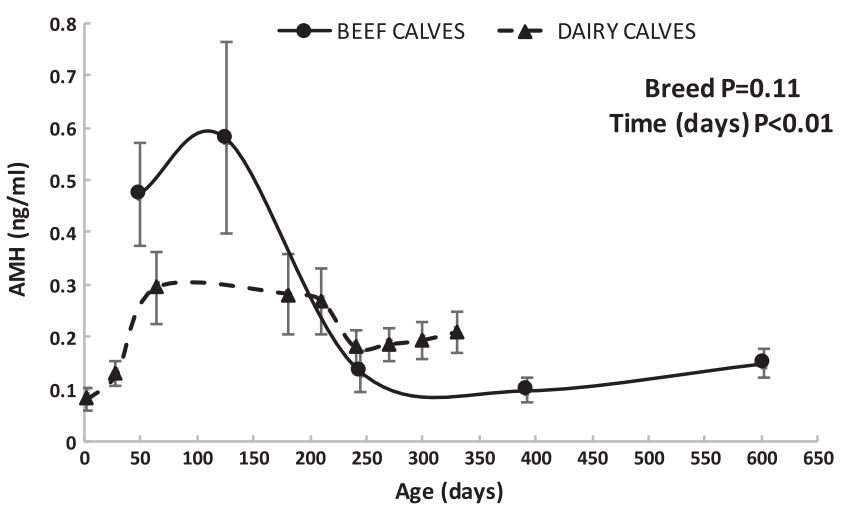

Figure 1 Circulating AMH concentrations $(\mathrm{ng} / \mathrm{mL})$ in dairy $(n=9$; unpublished) and cross bred beef ( $n=13$, modified from Mossa et al. (2013)) female calves. Results of ANOVA indicated that mean AMH concentrations were similar between dairy and beef calves $(P=0.11)$, but varied with time $(P<0.01)$.

others indicating that 3- to 4-month-old calves have greater $\mathrm{AMH}$ levels compared to young adult heifers in both Holstein (14-16 months) and Bos indicus Nelore (18-24 months) cattle (Batista et al. 2016). It can be assumed that $\mathrm{AMH}$ concentrations increase in the first months of life and decrease before puberty in cattle, like women (Hagen et al. 2011, Kelsey et al. 2011), but the timing of such fluctuations may vary among breeds and genetic groups. Prepubertal heifers experience waves of antral follicular growth like adult cattle and number of follicles increases from 2 to 14 weeks of age (Evans et al. 1994). Thus, it is plausible that the variations in $\mathrm{AMH}$ concentrations observed before puberty are reflective of changes in growth patterns of small antral follicles. Another possible explanation is that $\mathrm{AMH}$ prepubertal variations are due to changes in the ability of granulosa cells to secrete AMH. Nevertheless, if prepubertal concentrations of $\mathrm{AMH}$ would be used to predict the future reproductive function in adult cattle, the age at which samples are collected should be considered.

In prepubertal Rasa Aragonesa lambs (mainly bred for meat and wool production), AMH concentrations tended to increase from 3 to 4.5 months and to decline at 6 months of age, but the within-animal repeatability was low (Lahoz et al. 2014). In addition, AMH reached its peak at different times among animals, and prepubertal $\mathrm{AMH}$ was not correlated to $\mathrm{AMH}$ concentrations in adulthood (Lahoz et al. 2014). In Sarda ewe lambs (bred for milk production), AMH was not detectable in individuals with a low AFC; and, in those with a high AFC, AMH concentrations increased from 2 to 5 weeks and declined from 6 weeks of age (Torres-Rovira et al. 2016). These reports indicate that in sheep, prepubertal $\mathrm{AMH}$ concentrations vary considerably among animals and within individuals across age. Therefore, the potential application of prepubertal AMH as a predictor of the reproductive performance in adulthood in sheep appears limited. 
In women, $\mathrm{AMH}$ concentrations remain relatively constant during the menstrual cycle (Cook et al. 2000, Hehenkamp et al. 2006). Evidence is also accumulating that $\mathrm{AMH}$ concentrations vary minimally during estrous cycles in cattle. For example, we reported that a single $\mathrm{AMH}$ measurement in young adult beef heifers was highly correlated $(r=0.97)$ with the average for multiple AMH measurements during different days of the same or multiple estrous cycles (Ireland et al. 2011). In Holstein cows, AMH varied minimally during the same estrous cycle (Rico et al. 2009, Souza et al. 2015) and on different days of two estrous cycles (Rico et al. 2009). Also, AMH concentrations were similar within the same individual during natural and synchronized estrous cycles in dairy cows (Pfeiffer et al. 2014). Taken together these findings illustrate the static nature of $\mathrm{AMH}$ during the estrous cycle and its repeatability across multiple estrous cycles in cattle. This important finding confirms the usefulness of a single blood sample to reliably determine $\mathrm{AMH}$ concentrations in adult cattle.

\section{Factors that impact circulating AMH concentrations}

\section{Developmental programming: nutrition, disease, lactation and endocrine disruptors}

The environment encountered during fetal life exerts a profound influence on development, physiological function and risk of disease in adult mammals (Barker 2007, Langley-Evans \& McMullen 2010). A stimulus or an insult at a critical and sensitive period of fetal or perinatal life has permanent effects on the structure, physiology and metabolism of different organs and systems. This process is named 'programming'. Interest is growing on the potential for programming of the reproductive system in mammals (reviewed by Sloboda et al. 2011, Evans et al. 2012, Mossa et al. 2015), albeit studies investigating programming of the size of the ovarian reserve, and correspondingly of $\mathrm{AMH}$ production, in cattle are scarce.

Maternal nutritional status is considered a major cause of fetal developmental programming in humans, cattle and sheep (Gluckman \& Hanson 2004, McMillen et al. 2008, El Hajj et al. 2014, Mossa et al. 2015). We tested the hypothesis in cattle that dietary nutritional restriction (to $60 \%$ of maternal requirements) has permanent effects on the establishment of the ovarian reserve (total number of morphologically healthy follicles and oocytes) in offspring. We imposed the dietary restriction during the first trimester of pregnancy to coincide with the peak in the number of germ cells in fetal ovaries (Erickson 1966). Female calves born to nutritionally restricted mothers had a diminished ovarian reserve (Mossa et al. 2013) as assessed by consistently lower circulating $\mathrm{AMH}$ concentrations from 4 months to 1.8 years of age, lower antral follicle count (AFC, number of antral follicles growing during follicular waves) from 7 weeks to 1.6 years of age and increased FSH concentrations, a phenotypic characteristic of cattle with a low AFC (Burns et al. 2005, Ireland et al. 2007, JimenezKrassel et al. 2009, Mossa et al. 2010). Interestingly, these heifers had similar birth weights, postnatal growth rates and age at puberty compared to offspring from control mothers (Mossa et al. 2013). This finding implies that the formation of the ovarian reserve during embryo/fetal development may be very sensitive to diet manipulation during the first trimester of pregnancy.

Another study reported that high levels of protein fed to dams in the second trimester of gestation reduced the number of healthy antral follicles in the offspring of beef heifers, but AMH concentrations were not measured (Sullivan et al. 2010). Rats whose mothers were fed a high-fat diet from conception until the end of lactation had reduced AMH signaling as neonates, but an increased number of primordial and transitioning follicles and higher $\mathrm{AMH}$ expression levels as adults compared to offspring of control dams (Tsoulis et al. 2016). Further, overfed newborn rats showed a trend for decreased AMH expression (Sominsky et al. 2016); whereas, in cattle, maternal overnutrition decreased fetal ovarian follicular development (Weller et al. 2016). These studies, albeit using different experimental models and different dietary regimes, provide evidence for the programming of ovarian development and hence of $\mathrm{AMH}$ secretion in adulthood in response to nutritional imbalances imposed during fetal life. These findings indicate that both maternal undernutrition and overnutrition reduce AMH circulating concentrations in offspring. Because of the potential impact of maternal nutrition on fertility in female offspring, the effect of maternal diet on the development of the ovarian reserve, and in turn, $\mathrm{AMH}$ concentrations, clearly warrants further research.

Another aspect of the concomitant lactational and gestational status in dairy cow is the potential impact of mammary inflammation on fetal developmental programming. Many studies have investigated the developmental origins of different reproductive disorders in humans (Ho et al. 2017), but experimental evidence on the potential effects of maternal disease during pregnancy on the ovarian development and function is lacking. Dairy cows with a high number of somatic cell count (SCC) in milk, an index of chronic mammary gland infection (Caraviello et al. 2005), produced daughters with reduced $\mathrm{AMH}$ concentrations as young adults (Ireland et al. 2011). These results, albeit preliminary, imply that persistent mammary infection in the dam during gestation may not only impair her milk production but also have a long-term negative impact on the reproductive potential of her female offspring.

Finally, the potential impact of endocrine-disrupting compounds, natural and artificial components as well as environmental chemicals that may interfere with the physiological actions of hormones, on the offspring 
health and reproduction need to be considered (reviewed by Padmanabhan and Veiga-Lopez (2014)). In sheep, excess testosterone exposure prenatally from days 30 to 90 of gestation reduced $\mathrm{AMH}$ protein expression in granulosa cells of preantral follicles, but it increased $\mathrm{AMH}$ expression in antral follicles of young adult ewes compared to controls. In the same study, no effect was detected in prepubertal female lambs (VeigaLopez et al. 2012). These findings indicate that prenatal testosterone induces changes in $\mathrm{AMH}$ expression, implying that testosterone has a role in regulation of the ovarian reserve.

Taken together, these studies provide evidence for the negative impact on $\mathrm{AMH}$ concentrations, and in turn, on the establishment of the ovarian reserve, of different factors that may act during fetal life, specifically nutritional imbalances (under and overnutrition), disease, lactation and endocrine disruptors.

\begin{abstract}
Aging
$\mathrm{AMH}$ is considered an excellent clinical indicator of ovarian aging in women (Nelson et al. 2012), because, like AFC, circulating AMH concentrations show a high correlation with the size of the ovarian reserve that declines with age (Hansen et al. 2011). During aging in mice, the decline in serum $\mathrm{AMH}$ concentrations correlates positively with the decline in the number of primordial follicles (Kevenaar et al. 2006). Investigations on ovarian aging in domestic species are lacking. A study conducted on primiparous and pluriparous Holstein cows reported no correlation between $\mathrm{AMH}$ and parity (Souza et al. 2015), whereas another study reported higher $\mathrm{AMH}$ concentrations in cows on the second and third lactations compared to those on the first and fourth or greater lactations (Ribeiro et al. 2014). These observations imply that $\mathrm{AMH}$ concentrations do not decline coincident with the first few years of age in cattle.
\end{abstract}

\section{Breed}

Correlation of $\mathrm{AMH}$ concentrations and size of the ovarian reserve in different breeds of cattle have not been reported. However, several studies indicate that AMH concentrations and follicle numbers may be lower in dairy compared with beef cattle. In our laboratory, for example, we have summarized circulating $\mathrm{AMH}$ concentrations and follicle numbers and ovarian size determined via ovarian ultrasonography approximately $96 \mathrm{~h}$ after prostaglandin $\mathrm{F}_{2 \alpha}$ treatment for 12- to 16-month-old Holstein dairy and crossbred beef (primarily Angus $\times$ Charolais) heifers (Jimenez and Ireland, unpublished). Results (Fig. 2) showed that follicle numbers, ovary size and AMH concentrations were lower $(P<0.01)$ in dairy compared with beef heifers. We also measured AMH concentrations in crossbred dairy Holstein and beef prepubertal female

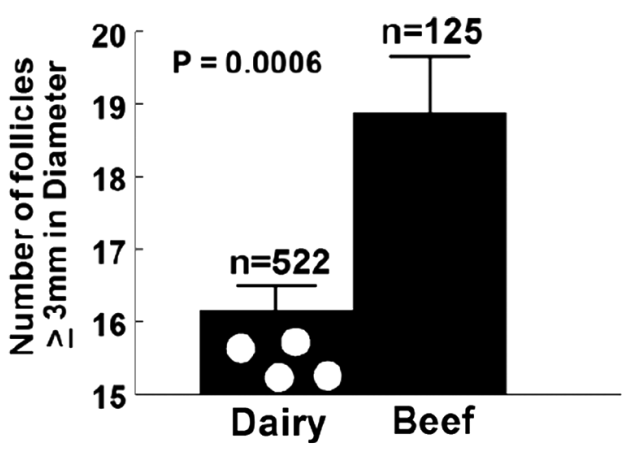

\section{2 to 16 month old adult heifers}
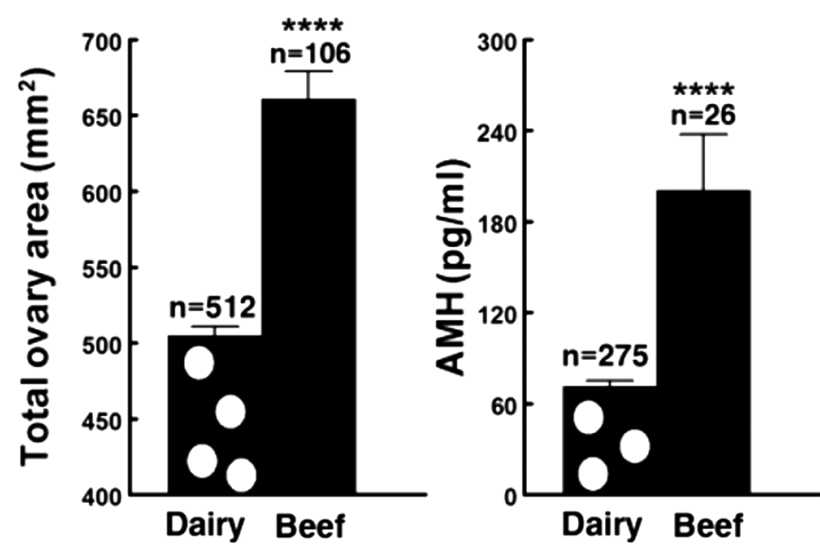

Figure 2 Number of follicles $\geq 3 \mathrm{~mm}$ in diameter (top panel), total ovarian area $\left(\mathrm{mm}^{2}\right)$ determined using ovarian ultrasonography and circulating $\mathrm{AMH}$ concentrations (pg/mL) (bottom panel) approximately $96 \mathrm{~h}$ after prostaglandin $\mathrm{F}_{2 \alpha}$ treatment in 12- to 16-month-old Holstein dairy and crossbred (primarily Angus $\times$ Charolais) heifers (Jimenez and Ireland unpublished). Asterisks indicate differences between dairy vs beef $(* * * * P<0.01)$.

calves using the same assay, but we failed to detect a statistically significant difference, possibly because blood samples were collected on different days in dairy and beef calves (Fig. 1). Nevertheless, others report that young adult beef (Angus and Charolais) heifers had increased $\mathrm{AMH}$ concentrations compared with dairy (Holstein and Jersey) heifers (Pfeiffer et al. 2014). Also, Nelore (Bos indicus) zebu beef heifers presented greater plasma $\mathrm{AMH}$ concentrations coupled with a larger ovarian antral follicle population than Holstein (Bos taurus) heifers (Batista et al. 2014).

Whether $\mathrm{AMH}$ concentrations differ among dairy breeds, however, is controversial. AMH did not differ between Holstein and Jersey heifers (Pfeiffer et al. 2014). Nevertheless, another study conducted on a larger number of animals reports different $\mathrm{AMH}$ concentrations among dairy breeds with Jersey cows having the greatest $\mathrm{AMH}$ concentrations followed by crossbreds (Holstein $\times$ Jersey) and then Holstein (Ribeiro et al. 2014). Further, Gyr (Bos indicus) dairy zebu heifers had greater $\mathrm{AMH}$ concentrations compared 
to Murrah buffalo (Bubalus bubalis) and Holstein heifers (Baldrighi et al. 2014). Thus, it can be assumed that AMH concentrations (1) are higher in beef compared to dairy cattle and (2) vary among genetic groups and breeds among dairy cattle. Whether the relatively low $\mathrm{AMH}$ in dairy compared with beef cattle implies they may also have an inherently smaller ovarian reserve, which may contribute to the poorer fertility after calving in dairy compared to beef cows, is unknown.

\section{Granulosa cells}

Cattle with a low AFC respond poorly to gonadotropin stimulation during superovulation (Ireland et al. 2007); hence, the capacity of granulosa cells to respond to FSH was hypothesized to be diminished in individuals with low vs a high AFC (Scheetz et al. 2012). To test this hypothesis, an in vitro model was developed to determine whether FSH action on granulosa cells differed between individuals with low compared to high AFC. Concentration of $\mathrm{AMH}$ and expression of $\mathrm{AMH}$ mRNA were assessed, among a variety of other biomarkers for FSH action, in granulosa cells exposed to different doses of FSH. The basal capacity of untreated granulosa cells to produce $\mathrm{AMH}$ was two-fold greater in the high compared to the low AFC group (Fig. 3). Further, granulosa cells from both groups responded in a dose-response fashion to $\mathrm{FSH}$ stimulation, but overall $\mathrm{AMH}$ concentrations and abundance of AMH mRNA for all FSH doses were lower in the low vs high AFC groups. This finding indicated that granulosa cells from the low AFC group responded minimally to FSH. Cattle with a low AFC have chronically heightened FSH secretion (Burns et al. 2005, Ireland et al. 2007, Jimenez-Krassel et al. 2009, Mossa et al. 2010), which may result in the desensitization or uncoupling of $\mathrm{FSH}$ receptors from $\mathrm{FSH}$ in granulosa cells (Amsterdam et al. 2002). This could explain why granulosa cells in cattle with a low AFC were refractory to FSH action and consequently produced less $\mathrm{AMH}$ compared to granulosa cells from cattle with a high AFC. In addition, the refractoriness of granulosa cells to FSH could also at least partially explain why cattle (Kawamata 1994, Cushman et al. 1999, Taneja et al. 2000, Singh et al. 2004, Ireland et al. 2007) and women (Beckers et al. 2002, Broekmans et al. 2006, Styer \& Toth 2011, Dewailly et al. 2014) with a small ovarian reserve and correspondingly chronically high FSH secretion during reproductive cycles respond poorly to $\mathrm{FSH}$ stimulation during assisted reproductive technologies.

\section{Correlation of circulating AMH concentrations with ovarian follicle numbers (AFC during follicular waves) and the ovarian reserve}

Peripheral AMH concentrations are positively associated with the total number of healthy follicles and oocytes
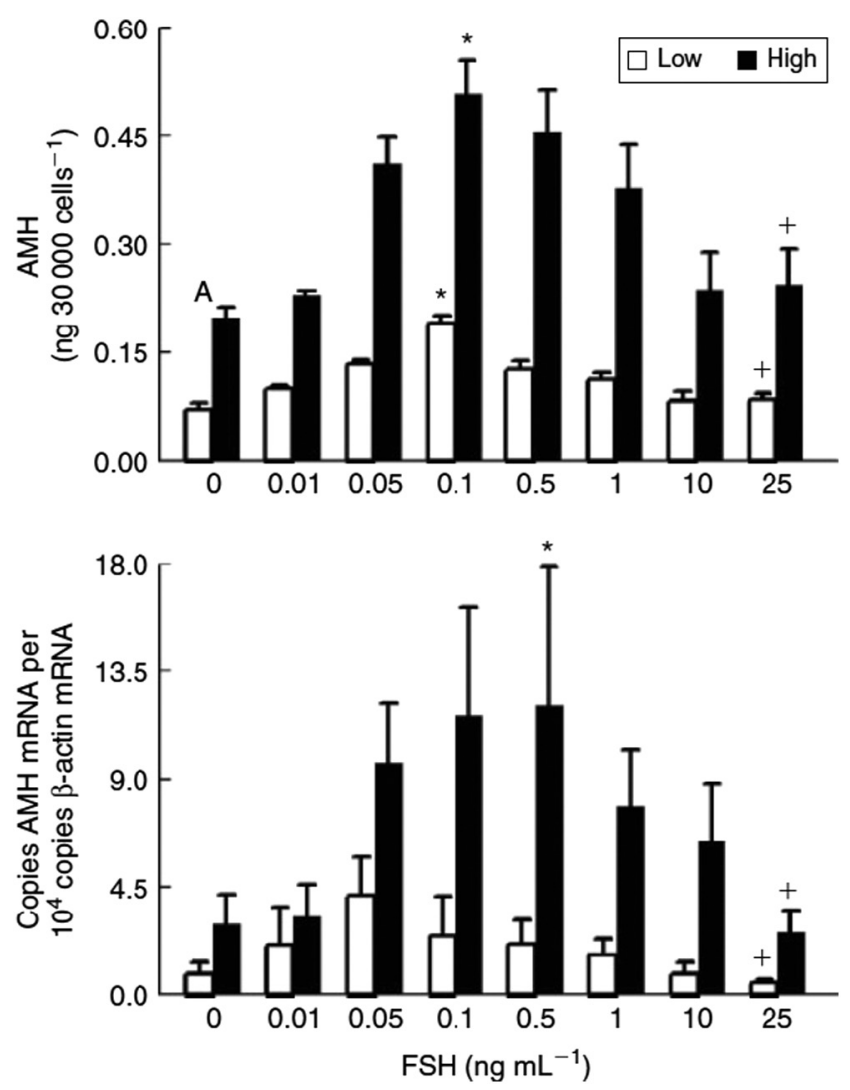

Figure 3 Effect of FSH on AMH production and abundance of $\mathrm{AMH}$ mRNA by granulosa cells from cattle with a high vs a low AFC. Granulosa cells were treated in vitro with various concentrations of $\mathrm{FSH}$ for 6 days. AMH production (top panel) and abundance of $\mathrm{AMH}$ mRNA (bottom panel) were measured on Day 6 of culture in the high and low AFC groups. Bars represent the mean \pm S.E.M. for 3 pools of granulosa cells from 3 to 5 cows per pool. Each pool contained media or cells from 6 culture wells combined. Results of ANOVA indicated that overall $\mathrm{AMH}$ concentrations and abundance of $\mathrm{AMH}$ mRNA for all FSH doses $(0-25 \mathrm{ng} / \mathrm{mL})$ combined were higher $(P<0.001)$ for the high vs the low AFC group. In the top panel, the $\mathrm{A}$ above bars at the $0 \mathrm{FSH}$ dose indicates a significant $(P<0.01)$ difference between means. In addition, the asterisk above bars indicates that $\mathrm{AMH}$ production increased $(P<0.001)$ linearly in response to FSH doses from 0 to $0.1 \mathrm{ng} / \mathrm{mL}$. The plus symbol indicates that $\mathrm{AMH}$ production decreased $(P<0.05)$ linearly in response to doses of $\mathrm{FSH}>0.1 \mathrm{ng} / \mathrm{mL}$. In the bottom panel, the asterisk above bars in the high AFC group indicates that abundance of AMH mRNA increased $(P<0.05)$ linearly in response to FSH doses from 0 to $0.5 \mathrm{ng} / \mathrm{mL}$, whereas the plus symbol above bars indicates that AMH mRNA abundance decreased $(P<0.05)$ linearly in response to $\mathrm{FSH}$ doses $>0.5 \mathrm{ng} / \mathrm{mL}$. Also, in the low AFC group, the plus symbol indicated that AMH mRNA decreased $(P<0.05)$ linearly in response to FSH doses $>0.05 \mathrm{ng} / \mathrm{mL}$. From Scheetz et al. (2012).

in ovaries of mice (Kevenaar et al. 2006) and with the number of healthy growing follicles in women (La Marca \& Volpe 2006). A high positive correlation $(r>0.90)$ was observed between the variation in $\mathrm{AMH}$, AFC and histological determination of total number of morphologically healthy follicles and oocytes in ovaries of young adult cattle (Ireland et al. 2008). In beef heifers, 
circulating $\mathrm{AMH}$ concentrations were approximately 6and 2-fold greater in animals with high ( $\geq 25$ follicles, $\geq 3 \mathrm{~mm}$ in diameter) or intermediate (16-24 follicles) compared with a low ( $\leq 15$ follicles) AFC during follicular waves. Also, the overall average $\mathrm{AMH}$ concentration during ovulatory follicular waves per animal was highly correlated $(r=0.92)$ with average peak AFC during the two or three waves of an estrous cycle (Ireland et al. 2008). In another study, AMH plasma concentrations were highly positively correlated with the numbers of 3-7 mm antral follicles detected by ovarian ultrasonography in primiparous dairy cattle (Rico et al. 2009). Also, a positive association was detected between the antral follicle population and circulating $\mathrm{AMH}$ concentrations in Murrah (Bubalus bubalus), Holstein (Bos taurus) and Gyr (Bos indicus) heifers (Baldrighi et al. 2014). It can be concluded, therefore, that $\mathrm{AMH}$ and $\mathrm{AFC}$ are positively correlated in cattle (Ireland et al. 2008, Rico et al. 2009, Baldrighi et al. 2014) and both AFC and AMH can be used interchangeably and reliably to estimate total number of morphologically healthy follicles and oocytes in the ovaries (ovarian reserve) of an individual (Ireland et al. 2008).

\section{Use of AMH as a predictor of fertility}

The inherently high variation in the quantity of morphologically healthy follicles and oocytes in the ovarian reserve of individuals may be among the chief factors that contribute to the high variation in fertility among young adults. Thus, reliable biomarkers of the ovarian reserve such as AFC and AMH, which are highly positively correlated with each other, may be used to predict the reproductive potential of an individual. Extensive results have shown that both AFC and AMH are positively associated with several indicators of reproductive efficiency in cattle and sheep.

\section{Fertility}

When $\mathrm{AMH}$ concentrations were determined in prepubertal ewe lambs, $\mathrm{AMH}$ was higher in those animals that subsequently became pregnant after the first mating compared with individuals that became pregnant after the second mating or were not pregnant (Lahoz et al. 2012). Although similar studies have not been done in cattle, in our recent work, $\mathrm{AMH}$ concentrations were determined in young adult Holstein heifers at 11-12 months of age and a variety of fertility measurements made before and after calving in the same individuals. Results showed that conception rates to first artificial insemination (Al), services per conception and days open after calving until pregnant were similar among individuals in the different $\mathrm{AMH}$ quartiles before calving and during the first, second and third lactations. However, the quartile $(\mathrm{Q})$ of cows with the lowest $\mathrm{AMH}$ concentrations $(\mathrm{Q} 1)$ as heifers tended $(P<0.10)$ to be lower at each lactation and had the lowest overall average for total percentage pregnant compared with cows in Q2 or Q3 but not Q4 AMH quartiles (JimenezKrassel et al. 2015). These findings contrast somewhat with our other study that examined fertility in dairy cows (up to 8 parities) with low, intermediate or high AFC and presumably corresponding differences in $\mathrm{AMH}$ concentrations. In this study, dairy cows with a low AFC had a lower conception rate to first Al, greater number of $\mathrm{Al}$ to conceive and higher calving interval compared with cows with an intermediate or high AFC (Mossa et al. 2012). Like our finding for dairy cows with low AMH as a heifer (Jimenez-Krassel et al. 2015), overall pregnancy rate was lower for the dairy cows with a low compared with a high AFC (Mossa et al. 2012). Another study shows that dairy cows with high $\mathrm{AMH}$ had greater pregnancy rates and lower incidence of pregnancy loss between days 30 and 65 of gestation (Ribeiro et al. 2014). Lower fertility for cattle with a relatively low AFC is further supported by evidence of lower pregnancy rates in beef heifers with a low vs a higher AFC (Cushman et al. 2009) and by a study showing that lactating cows with a low AFC had a longer interval from calving to conception and lower pregnancy rates than cows with a high AFC (Martinez et al. 2016).

The reasons for the differences between some fertility measurements in the studies that classified cattle based on $\mathrm{AMH}$ or $\mathrm{AFC}$ are unknown but likely caused by relatively small numbers of cattle in $\mathrm{AMH}$ quartiles and some AFC groups coupled with mixed ages of cows in AFC groups. In addition, cross-sectional studies using older cows may be biased by previous removal (culling) of individuals from the herd with a relatively low AFC or $\mathrm{AMH}$. Nevertheless, combined results (Cushman et al. 2009, Mossa et al. 2012, Jimenez-Krassel et al. 2015, Martinez et al. 2016) imply that fertility is suboptimal in cows with low AMH concentrations as heifers and in cows with low AMH or a low AFC compared with herd mates with higher $\mathrm{AMH}$ concentrations or a higher AFC.

\section{Longevity}

In farm species, the ability to conceive with the minimum number of services and, the shortest time after calving and to deliver a healthy offspring, is essential for profitable farming, and this is particularly true for dairy cattle. Thus, we tested the hypothesis that cattle with the lowest $\mathrm{AMH}$ concentrations have suboptimal fertility and are removed from a herd for poor reproductive performance at a greater rate and therefore have a shorter productive herd life (time in herd after calving) compared with age-matched herd mates with higher AMH (Jimenez-Krassel et al. 2015). A single AMH measurement was made in 281, 11- to 15-month-old Holstein heifers. Records on reproductive performance, level of milk production, health and reasons for culling for each individual were collected. Animals were 


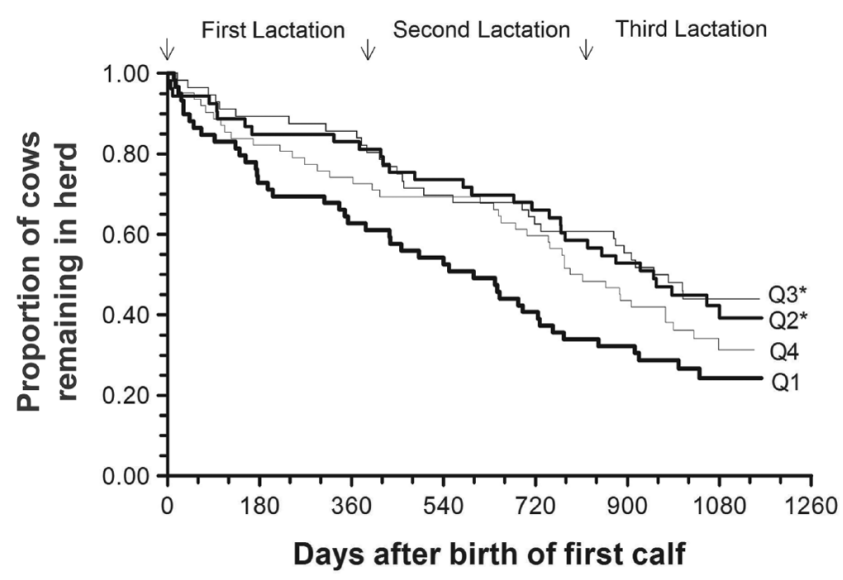

Figure 4 Kaplan-Meier plots of survival curves for proportion of Holstein cows in each $\mathrm{AMH}$ quartile (where Q1 = quartile of heifers with the lowest AMH concentration) remaining in the herd after birth of their first calf. Asterisk indicates that survival rate for Q1 differs from that for Q2 $(P<0.02)$ or Q3 $(P<0.01)$; survival rate in Q1 tended $(P=0.13)$ to differ from that in Q4. From JimenezKrassel et al. (2015).

partitioned into quartiles (Q1, Q2, Q3 and Q4) based on $\mathrm{AMH}$ concentrations as heifers and data were analyzed after animals completed three lactations. Q1 cows with the lowest $\mathrm{AMH}$ concentrations as heifers completed fewer lactations compared to Q3 cows and had a 180day average shorter productive herd life compared with Q2 and Q3 cows. By the end of the study 24, 37, 43 and $32 \%$ of the cows in Q1, Q2, Q3 and Q4 respectively remained in the herd, but the probability of being culled after birth of the first calf was higher for the Q1 compared with Q2, Q3 and Q4 cows (Fig. 4). Also, removal rate for poor reproductive performance compared with all other reasons for culling was greater for Q1 compared with Q2, Q3 and Q4 cows combined during the first lactation (Jimenez-Krassel et al. 2015). This study, albeit conducted on a limited number of animals, indicates that a single determination of $\mathrm{AMH}$ concentrations in young adult Holstein heifers is predictive of their future herd longevity. In addition, because level of milk production was not correlated with AMH concentrations (JimenezKrassel et al. 2015), the potential application of $\mathrm{AMH}$ assessment to identify heifers with superior reproductive performance without compromising milk production appears promising.

\section{Superovulation}

Both $\mathrm{AMH}$ and $\mathrm{AFC}$ are used to predict the response to ovarian stimulatory treatments during ART (Broekmans et al. 2006). Such responsiveness is negatively associated with aging and is linked to a reduction in number of follicles and oocytes in ovaries in women (Beckers et al. 2002, Styer \& Toth 2011, Dewailly et al. 2014) and in cattle (Kawamata 1994,
Cushman et al. 1999, Taneja et al. 2000, Singh et al. 2004). We documented for the first time that young adult cattle with low AFC have a diminished responsiveness to superovulation (lower number of corpora lutea and of recovered embryos/unfertilized oocytes) and produced fewer high-quality embryos compared to age-matched cattle with high AFC (Ireland et al. 2007). Also in Taurus indicus Braford cattle (Bhraman $\times$ Hereford crossbred animals), AFC assessed before puberty was predictive of the response to superovulation at 24 months of age assessed by higher number of total oocytes and embryos recovered (Silva-Santos et al. 2014). Similarly in sheep, a positive association was observed between follicle numbers and responsiveness to superovulation in both adult and prepubertal individuals (Mossa et al. 2007, Torres-Rovira et al. 2014). In summary, it is clear that AFC represents a reliable index of the ovarian response to stimulation in cattle and sheep, as it is in women (Broekmans et al. 2006).

Evidence is now growing to support the use of AMH as a predictor of the responsiveness to ovarian stimulatory treatment in agricultural species. In primiparous dairy cows, AMH concentrations before the superovulatory treatment were positively correlated with the number of follicles before treatment and with the numbers of large follicles and corpora lutea $(\mathrm{CL})$ after treatment (Rico et al. 2009). In non-lactating Holstein cows, plasma AMH concentrations before gonadotropin treatments were highly correlated with the numbers of large follicles and oocytes recovered at ovum pick up (OPU), as well as with the number of large follicles at estrus and the number of embryos collected from multiple ovulation and embryo transfer protocols (Rico et al. 2012). Further, in Japanese Black beef cattle, AMH concentrations were positively correlated with the number of follicles, number of oocytes/embryos recovered fertilized embryos and transferable embryos (Hirayama et al. 2012). In lactating Holstein cows, AMH concentrations for each individual cow were correlated with superovulation response (number of $\mathrm{CL}$ on the day of the flush), total oocytes collected and total transferable embryos. Also, when cows were classified into quartiles of circulating $\mathrm{AMH}, \mathrm{Q} 4$ cows had a $>2$-fold greater response to superovulation including embryo production compared with cows (Souza et al. 2015).

A positive correlation between $\mathrm{AMH}$ and OPU coupled with in vitro embryo production was established in Holstein (Vernunft et al. 2015), beef (Korean Hanwoo) (Ghanem et al. 2016) and Bos Indicus (Zebu) cattle (Guerreiro et al. 2014). In addition, AMH concentrations before treatment were predictive of the response to superovulation in sheep (Lahoz et al. 2014), goats (Monniaux et al. 2011) and mares (Claes \& Ball 2016). These findings confirm the positive association between the response to superovulation and the ovarian reserve and support the use of $\mathrm{AMH}$ assessment to select donors for embryo production. In addition, elimination of 
recipients with low $\mathrm{AMH}$ or low AFC may also improve success of embryo transfer in cattle.

\section{Summary and conclusion}

Evidence indicates that $\mathrm{AMH}$ concentrations in cattle (1) increases in the first months of age and decreases thereafter until puberty; (2) is repeatable in the same or multiple estrous cycles within individual young adults; (3) can be negatively programmed by factors acting during fetal life (i.e. maternal undernutrition, mastitis, excess testosterone); (4) is higher in dairy than beef breeds and varies among breeds and genetic groups; (5) is positively correlated with AFC; (6) is a reliable indicator of the total number of ovarian follicles and oocytes and (7) is positively associated with measures of fertility (pregnancy rate, herd longevity and response to superovulation). Taken together, these findings support the potential use of $\mathrm{AMH}$ as a predictor of fertility and longevity in cattle.

Most reproductive traits are lowly heritable $(0.02-$ 0.04) in cattle (Berry et al. 2014). However, we have recently shown that $\mathrm{AFC}$ is moderately heritable in dairy cows $(0.30 \pm 0.14)$ and heifers $(0.25 \pm 0.13)$ (Walsh et al. 2014). As AFC is highly correlated with $\mathrm{AMH}$ concentrations and size of the ovarian reserve (Ireland et al. 2008, Rico et al. 2009, Baldrighi et al. 2014), it is plausible that AMH, like AFC, may be moderately heritable. If true, $\mathrm{AMH}$ could be included among the traits used to select males and hence improve animal breeding schemes.

In addition, because levels of milk production were not correlated with AMH concentrations (JimenezKrassel et al. 2015), the potential application of $\mathrm{AMH}$ assessment to identify heifers with a superior reproductive performance without compromising milk production appears promising. In contrast to cattle, the limited number of studies conducted in sheep indicate that $\mathrm{AMH}$ concentrations before puberty are not correlated with AMH in adulthood (Lahoz et al. 2014) but are positively associated with fertility at first mating. In this and other farm species, the potential association between $\mathrm{AMH}$ and reproductive performance remains largely unexplored.

\section{Declaration of interest}

The authors declare that there is no conflict of interest that could be perceived as prejudicing the impartiality of this review.

\section{Funding}

The work by J J I was supported by National Research Initiative Competitive Grant no. 2007-35203-18178 and Animal and Food Research Institute Competitive Grant no.
2013-67015-20962 from the USDA National Institute of Food and Agriculture and funds from the Michigan AgBioResearch. The work by $\mathrm{F} M$ was supported by the Irish Department of Agriculture, Food and the Marine (RSF-06-328) and Science Foundation Ireland (07/SRC/B1156) and is now financed by the Italian Ministry of University and Research (Rita Levi Montalcini Grant 2010).

\section{Acknowledgements}

The authors thank Green Meadows Farms, Inc. for use of cattle.

\section{References}

Amsterdam A, Hanoch T, Dantes A, Tajima K, Strauss JF \& Seger R 2002 Mechanisms of gonadotropin desensitization. Molecular and Cellular Endocrinology 187 69-74. (doi:10.1016/S0303-7207(01)00701-8)

Baldrighi J, Sá Filho MF, Batista EO, Lopes RN, Visintin JA, Baruselli PS \& Assumpção ME 2014 Anti-Mullerian hormone concentration and antral ovarian follicle population in Murrah heifers compared to Holstein and Gyr kept under the same management. Reproduction in Domestic Animals 49 1015-1020. (doi:10.1111/rda.12430)

Barker DJ 2007 The origins of the developmental origins theory. Journal of Internal Medicine 261 412-417. (doi:10.1111/j.13652796.2007.01809.x)

Batista EO, Macedo GG, Sala RV, Ortolan MD, Sá Filho MF, Del Valle TA, Jesus EF, Lopes RN, Rennó FP \& Baruselli PS 2014 Plasma antimullerian hormone as a predictor of ovarian antral follicular population in Bos indicus (Nelore) and Bos taurus (Holstein) heifers. Reproduction in Domestic Animals 49 448-452. (doi:10.1111/rda.12304)

Batista EO, Guerreiro BM, Freitas BG, Silva JC, Vieira LM, Ferreira RM, Rezende RG, Basso AC, Lopes RN, Rennó FP et al. 2016 Plasma antiMüllerian hormone as a predictive endocrine marker to select Bos taurus (Holstein) and Bos indicus (Nelore) calves for in vitro embryo production. Domestic Animal Endocrinology 54 1-9. (doi:10.1016/j. domaniend.2015.08.001)

Beckers NG, Macklon NS, Eijkemans MJ \& Fauser BC 2002 Women with regular menstrual cycles and a poor response to ovarian hyperstimulation for in vitro fertilization exhibit follicular phase characteristics suggestive of ovarian aging. Fertility and Sterility 78 291-297. (doi:10.1016/S00150282(02)03227-2)

Berry DP, Wall E \& Pryce JE 2014 Genetics and genomics of reproductive performance in dairy and beef cattle. Animal 8 (Supplement 1) 105-121. (doi:10.1017/S1751731114000743)

Broekmans FJ, Kwee J, Hendriks DJ, Mol BW \& Lambalk CB 2006 A systematic review of tests predicting ovarian reserve and IVF outcome. Human Reproduction Update 12 685-718. (doi:10.1093/humupd/ dml034)

Burns DS, Jimenez-Krassel F, Ireland JL, Knight PG \& Ireland JJ 2005 Numbers of antral follicles during follicular waves in cattle: evidence for high variation among animals, very high repeatability in individuals, and an inverse association with serum follicle-stimulating hormone concentrations. Biology of Reproduction 73 54-62. (doi:10.1095/ biolreprod.104.036277)

Bézard J, Vigier B, Tran D, Mauléon P \& Josso N 1987 Immunocytochemical study of anti-Müllerian hormone in sheep ovarian follicles during fetal and post-natal development. Journal of Reproduction and Fertility $\mathbf{8 0}$ 509-516. (doi:10.1530/jrf.0.0800509)

Caraviello DZ, Weigel KA, Shook GE \& Ruegg PL 2005 Assessment of the impact of somatic cell count on functional longevity in Holstein and Jersey cattle using survival analysis methodology. Journal of Dairy Science 88 804-811. (doi:10.3168/jds.S0022-0302(05)72745-4)

Cate RL, Mattaliano RJ, Hession C, Tizard R, Farber NM, Cheung A, Ninfa EG, Frey AZ, Gash DJ \& Chow EP 1986 Isolation of the bovine and human genes for Müllerian inhibiting substance and expression of the human gene in animal cells. Cell 45 685-698. (doi:10.1016/00928674(86)90783-X)

Claes AN \& Ball BA 2016 Biological functions and clinical applications of anti-Müllerian hormone in stallions and mares. Veterinary Clinics 
of North America: Equine Practice 32 451-464. (doi:10.1016/j. cveq.2016.07.004)

Cook CL, Siow Y, Taylor S \& Fallat ME 2000 Serum müllerian-inhibiting substance levels during normal menstrual cycles. Fertility and Sterility $\mathbf{7 3}$ 859-861. (doi:10.1016/S0015-0282(99)00639-1)

Cushman RA, DeSouza JC, Hedgpeth VS \& Britt JH 1999 Superovulatory response of one ovary is related to the micro- and macroscopic population of follicles in the contralateral ovary of the cow. Biology of Reproduction 60 349-354. (doi:10.1095/biolreprod60.2.349)

Cushman RA, Allan MF, Kuehn LA, Snelling WM, Cupp AS \& Freetly HC 2009 Evaluation of antral follicle count and ovarian morphology in crossbred beef cows: investigation of influence of stage of the estrous cycle, age, and birth weight. Journal of Animal Science 87 1971-1980. (doi:10.2527/jas.2008-1728)

Dewailly D, Andersen CY, Balen A, Broekmans F, Dilaver N, Fanchin R, Griesinger G, Kelsey TW, La Marca A, Lambalk C et al. 2014 The physiology and clinical utility of anti-Mullerian hormone in women. Human Reproduction Update 20 370-385. (doi:10.1093/humupd/ dmt062)

Durlinger AL, Kramer P, Karels B, de Jong FH, Uilenbroek JT, Grootegoed JA \& Themmen AP 1999 Control of primordial follicle recruitment by anti-Müllerian hormone in the mouse ovary. Endocrinology $\mathbf{1 4 0}$ 5789-5796. (doi:10.1210/en.140.12.5789)

Durlinger AL, Gruijters MJ, Kramer P, Karels B, Kumar TR, Matzuk MM, Rose UM, de Jong FH, Uilenbroek JT, Grootegoed JA et al. 2001 AntiMüllerian hormone attenuates the effects of FSH on follicle development in the mouse ovary. Endocrinology 142 4891-4899. (doi:10.1210/ en.142.11.4891)

El Hajj N, Schneider E, Lehnen H \& Haaf T 2014 Epigenetics and lifelong consequences of an adverse nutritional and diabetic intrauterine environment. Reproduction 148 R111-R120. (doi:10.1530/REP-140334)

Erickson BH 1966 Development and senescence of the postnatal bovine ovary. Journal of Animal Science 25 800-805. (doi:10.2527/ jas1966.253800x)

Evans AC, Adams GP \& Rawlings NC 1994 Follicular and hormonal development in prepubertal heifers from 2 to 36 weeks of age. Journal of Reproduction and Fertility 102 463-470. (doi:10.1530/jrf.0.1020463)

Evans AC, Mossa F, Walsh SW, Scheetz D, Jimenez-Krassel F, Ireland JL, Smith GW \& Ireland JJ 2012 Effects of maternal environment during gestation on ovarian folliculogenesis and consequences for fertility in bovine offspring. Reproduction in Domestic Animals 47 (Supplement 4) 31-37. (doi:10.1111/j.1439-0531.2012.02052.x)

Ghanem N, Jin JI, Kim SS, Choi BH, Lee KL, Ha AN, Song SH \& Kong IK 2016 The anti-Müllerian hormone profile is linked with the in vitro embryo production capacity and embryo viability after transfer but cannot predict pregnancy outcome. Reproduction in Domestic Animals 51 301-310. (doi:10.1111/rda.12681)

Gluckman PD \& Hanson MA 2004 Living with the past: evolution, development, and patterns of disease. Science 305 1733-1736. (doi:10.1126/science.1095292)

Guerreiro BM, Batista EO, Vieira LM, Sá Filho MF, Rodrigues CA, Castro Netto A, Silveira CR, Bayeux BM, Dias EA, Monteiro FM et al. 2014 Plasma anti-mullerian hormone: an endocrine marker for in vitro embryo production from Bos taurus and Bos indicus donors. Domestic Animal Endocrinology 49 96-104. (doi:10.1016/j.domaniend.2014.07.002)

Hagen CP, Aksglaede L, Sørensen K, Mouritsen A \& Juul A 2011 Clinical use of anti-Müllerian hormone $(\mathrm{AMH})$ determinations in patients with disorders of sex development: importance of sex- and age-specific reference ranges. Pediatric Endocrinology Reviews 9 (Supplement 1) 525-528.

Hansen KR, Hodnett GM, Knowlton N \& Craig LB 2011 Correlation of ovarian reserve tests with histologically determined primordial follicle number. Fertility and Sterility 95 170-175. (doi:10.1016/j. fertnstert.2010.04.006)

Hehenkamp WJ, Looman CW, Themmen AP, de Jong FH, Te Velde ER \& Broekmans FJ 2006 Anti-Müllerian hormone levels in the spontaneous menstrual cycle do not show substantial fluctuation. Journal of Clinical Endocrinology and Metabolism 91 4057-4063. (doi:10.1210/jc.20060331)

Hirayama H, Kageyama S, Naito A, Fukuda S, Fujii T \& Minamihashi A 2012 Prediction of superovulatory response in Japanese Black cattle using ultrasound, plasma anti-Müllerian hormone concentrations and polymorphism in the ionotropic glutamate receptor AMPA1/GRIA1. Journal of Reproduction and Development 58 380-383. (doi:10.1262/ jrd.11-129S)

Ho SM, Cheong A, Adgent MA, Veevers J, Suen AA, Tam NN, Leung YK, Jefferson WN \& Williams CJ 2017 Environmental factors, epigenetics, and developmental origin of reproductive disorders. Reproductive Toxicology 68 85-104. (doi:10.1016/j.reprotox.2016.07.011)

Ireland JJ, Ward F, Jimenez-Krassel F, Ireland JL, Smith GW, Lonergan P \& Evans AC 2007 Follicle numbers are highly repeatable within individual animals but are inversely correlated with FSH concentrations and the proportion of good-quality embryos after ovarian stimulation in cattle. Human Reproduction 22 1687-1695. (doi:10.1093/humrep/ dem071)

Ireland JL, Scheetz D, Jimenez-Krassel F, Themmen AP, Ward F, Lonergan P, Smith GW, Perez GI, Evans AC \& Ireland JJ 2008 Antral follicle count reliably predicts number of morphologically healthy oocytes and follicles in ovaries of young adult cattle. Biology of Reproduction 79 1219-1225. (doi:10.1095/biolreprod.108.071670)

Ireland JJ, Smith GW, Scheetz D, Jimenez-Krassel F, Folger JK, Ireland JLH, Mossa F, Lonergan P \& Evans ACO 2011 Does size matter in females? An overview of the impact of the high variation in the ovarian reserve on ovarian function and fertility, utility of anti-Mullerian hormone as a diagnostic marker for fertility and causes of variation in the ovarian reserve in cattle. Reproduction, Fertility and Development 23 1-14. (doi:10.1071/RD10226)

Jimenez-Krassel F, Folger JK, Ireland JL, Smith GW, Hou X, Davis JS, Lonergan P, Evans AC \& Ireland JJ 2009 Evidence that high variation in ovarian reserves of healthy young adults has a negative impact on the corpus luteum and endometrium during estrous cycles in cattle. Biology of Reproduction 80 1272-1281. (doi:10.1095/biolreprod.108.075093)

Jimenez-Krassel F, Scheetz DM, Neuder LM, Ireland JL, Pursley JR, Smith GW, Tempelman RJ, Ferris T, Roudebush WE, Mossa F et al. 2015 Concentration of anti-Müllerian hormone in dairy heifers is positively associated with productive herd life. Journal of Dairy Science $\mathbf{9 8}$ 3036-3045. (doi:10.3168/jds.2014-8130)

Josso N, Cate RL, Picard JY, Vigier B, di Clemente N, Wilson C, Imbeaud S, Pepinsky RB, Guerrier D \& Boussin L 1993 Anti-müllerian hormone: the Jost factor. Recent Progress in Hormone Research 48 1-59.

Jost A 1947 The age factor in the castration of male rabbit fetuses. Proceedings of the Society for Experimental Biology and Medicine 66 302. (doi:10.3181/00379727-66-16071)

Kawamata M 1994 Relationships between the number of small follicles prior to superovulatory treatment and superovulatory response in Holstein cows. Journal of Veterinary Medical Science 56 965-967. (doi:10.1292/jvms.56.965)

Kelsey TW, Wright P, Nelson SM, Anderson RA \& Wallace WH 2011 A validated model of serum anti-müllerian hormone from conception to menopause. PLoS ONE 6 e22024. (doi:10.1371/journal.pone.0022024)

Kevenaar ME, Meerasahib MF, Kramer P, van de Lang-Born BM, de Jong FH, Groome NP, Themmen AP \& Visser JA 2006 Serum anti-mullerian hormone levels reflect the size of the primordial follicle pool in mice. Endocrinology 147 3228-3234. (doi:10.1210/en.2005-1588)

La Marca A \& Volpe A 2006 Anti-Mullerian hormone (AMH) in female reproduction: is measurement of circulating $\mathrm{AMH}$ a useful tool? Clinical Endocrinology 64 603-610. (doi:10.1111/j.1365-2265.2006.02533.x)

Lahoz B, Alabart JL, Monniaux D, Mermillod P \& Folch J 2012 AntiMüllerian hormone plasma concentration in prepubertal ewe lambs as a predictor of their fertility at a young age. BMC Veterinary Research $\mathbf{8}$ 118. (doi:10.1186/1746-6148-8-118)

Lahoz B, Alabart JL, Cocero MJ, Monniaux D, Echegoyen E, Sánchez P \& Folch J 2014 Anti-Müllerian hormone concentration in sheep and its dependence of age and independence of BMP15 genotype: an endocrine predictor to select the best donors for embryo biotechnologies. Theriogenology 81 347-357. (doi:10.1016/j. theriogenology.2013.09.033)

Langley-Evans SC \& McMullen S 2010 Developmental origins of adult disease. Medical Principles and Practice 19 87-98. (doi:10.1159/000273066)

Martinez MF, Sanderson N, Quirke LD, Lawrence SB \& Juengel JL 2016 Association between antral follicle count and reproductive measures in New Zealand lactating dairy cows maintained in a pasture-based 
production system. Theriogenology 85 466-475. (doi:10.1016/j. theriogenology.2015.09.026)

McGee EA \& Hsueh AJ 2000 Initial and cyclic recruitment of ovarian follicles. Endocrine Reviews 21 200-214. (doi:10.1210/edrv.21.2.0394)

McMillen IC, MacLaughlin SM, Muhlhausler BS, Gentili S, Duffield JL \& Morrison JL 2008 Developmental origins of adult health and disease: the role of periconceptional and foetal nutrition. Basic and Clinical Pharmacology and Toxicology 102 82-89. (doi:10.1111/j.17427843.2007.00188.x)

Monniaux D, Clemente N, Touzé JL, Belville C, Rico C, Bontoux M, Picard JY \& Fabre S 2008 Intrafollicular steroids and anti-mullerian hormone during normal and cystic ovarian follicular development in the cow. Biology of Reproduction 79 387-396. (doi:10.1095/ biolreprod.107.065847)

Monniaux D, Baril G, Laine AL, Jarrier P, Poulin N, Cognié J \& Fabre S 2011 Anti-Mullerian hormone as a predictive endocrine marker for embryo production in the goat. Reproduction 142 845-854. (doi:10.1530/REP11-0211)

Monniaux D, Drouilhet L, Rico C, Estienne A, Jarrier P, Touzé JL, Sapa J, Phocas F, Dupont J, Dalbiès-Tran R et al. 2012 Regulation of antiMüllerian hormone production in domestic animals. Reproduction Fertility and Development 25 1-16. (doi:10.1071/RD12270)

Mossa F, Duffy P, Naitana S, Lonergan P \& Evans ACO 2007 Association between numbers of ovarian follicles in the first follicle wave and superovulatory response in ewes. Animal Reproduction Science $\mathbf{1 0 0}$ 391-396. (doi:10.1016/j.anireprosci.2006.10.016)

Mossa F, Jimenez-Krassel F, Walsh S, Berry DP, Butler ST, Folger J, Smith GW, Ireland JL, Lonergan P, Ireland JJ et al. 2010 Inherent capacity of the pituitary gland to produce gonadotropins is not influenced by the number of ovarian follicles $\geq 3 \mathrm{~mm}$ in diameter in cattle. Reproduction Fertility and Development 22 550-557. (doi:10.1071/RD09100)

Mossa F, Walsh SW, Butler ST, Berry DP, Carter F, Lonergan P, Smith GW, Ireland JJ \& Evans AC 2012 Low numbers of ovarian follicles $\geq 3 \mathrm{~mm}$ in diameter are associated with low fertility in dairy cows. Journal of Dairy Science 95 2355-2361. (doi:10.3168/jds.2011-4325)

Mossa F, Carter F, Walsh SW, Kenny DA, Smith GW, Ireland JL, Hildebrandt TB, Lonergan P, Ireland JJ \& Evans AC 2013 Maternal undernutrition in cows impairs ovarian and cardiovascular systems in their offspring. Biology of Reproduction 88 1-9. (doi:10.1095/biolreprod.112.107235)

Mossa F, Walsh SW, Ireland JJ \& Evans ACO 2015 Early nutritional programming and progeny performance: is reproductive success already set at birth? Animal Frontiers 5 18-24. (doi:10.2527/af.2015-0004)

Nelson SM, Anderson RA, Broekmans FJ, Raine-Fenning N, Fleming R \& La Marca A 2012 Anti-Müllerian hormone: clairvoyance or crystal clear? Human Reproduction 27 631-636. (doi:10.1093/humrep/der446)

Padmanabhan V \& Veiga-Lopez A 2014 Reproduction Symposium: developmental programming of reproductive and metabolic health. Journal of Animal Science 92 3199-3210. (doi:10.2527/jas.2014-7637)

Pfeiffer KE, Jury LJ \& Larson JE 2014 Determination of anti-Müllerian hormone at estrus during a synchronized and a natural bovine estrous cycle. Domestic Animal Endocrinology 46 58-64. (doi:10.1016/j. domaniend.2013.05.004)

Ribeiro ES, Bisinotto RS, Lima FS, Greco LF, Morrison A, Kumar A, Thatcher WW \& Santos JE 2014 Plasma anti-Müllerian hormone in adult dairy cows and associations with fertility. Journal of Dairy Science $\mathbf{9 7}$ 6888-6900. (doi:10.3168/jds.2014-7908)

Rico C, Fabre S, Médigue C, di Clemente N, Clément F, Bontoux M, Touzé JL, Dupont M, Briant E, Rémy B et al. 2009 Anti-mullerian hormone is an endocrine marker of ovarian gonadotropin-responsive follicles and can help to predict superovulatory responses in the cow. Biology of Reproduction 80 50-59. (doi:10.1095/biolreprod.108.072157)

Rico C, Drouilhet L, Salvetti P, Dalbiès-Tran R, Jarrier P, Touzé JL, Pillet E, Ponsart C, Fabre S \& Monniaux D 2012 Determination of anti-Müllerian hormone concentrations in blood as a tool to select Holstein donor cows for embryo production: from the laboratory to the farm. Reproduction Fertility and Development 24 932-944. (doi:10.1071/RD11290)

Scheetz D, Folger JK, Smith GW \& Ireland JJ 2012 Granulosa cells are refractory to $\mathrm{FSH}$ action in individuals with a low antral follicle count. Reproduction Fertility and Development 24 327-336. (doi:10.1071/ RD11020)
Silva-Santos KC, Santos GM, Koetz Júnior C, Morotti F, Siloto LS, Marcantonio TN, Urbano MR, Oliveira RL, Lima DC \& Seneda MM 2014 Antral follicle populations and embryo production - in vitro and in vivo - of Bos indicus-taurus donors from weaning to yearling ages. Reproduction in Domestic Animals 49 228-232. (doi:10.1111/ rda.12255)

Singh J, Domínguez M, Jaiswal R \& Adams GP 2004 A simple ultrasound test to predict the superstimulatory response in cattle. Theriogenology $\mathbf{6 2}$ 227-243. (doi:10.1016/j.theriogenology.2003.09.020)

Sloboda DM, Hickey M \& Hart R 2011 Reproduction in females: the role of the early life environment. Human Reproduction Update 17 210-227. (doi:10.1093/humupd/dmq048)

Sominsky L, Ziko I, Soch A, Smith JT \& Spencer SJ 2016 Neonatal overfeeding induces early decline of the ovarian reserve: implications for the role of leptin. Molecular and Cellular Endocrinology 431 24-35. (doi:10.1016/j.mce.2016.05.001)

Souza AH, Carvalho PD, Rozner AE, Vieira LM, Hackbart KS, Bender RW, Dresch AR, Verstegen JP, Shaver RD \& Wiltbank MC 2015 Relationship between circulating anti-Müllerian hormone (AMH) and superovulatory response of high-producing dairy cows. Journal of Dairy Science $\mathbf{9 8}$ 169-178. (doi:10.3168/jds.2014-8182)

Styer AK \& Toth TL 2011 Antral follicle count in clinical practice: building the bridge from ovarian reserve to in vitro fertilization outcome. Fertility and Sterility 95 480-481; discussion 484-485. (doi:10.1016/j. fertnstert.2010.11.054)

Sullivan TM, Micke GC, Greer RM \& Perry VE 2010 Dietary manipulation of Bos indicusxheifers during gestation affects the prepubertal reproductive development of their bull calves. Animal Reproduction Science 118 131-139. (doi:10.1016/j.anireprosci.2009.07.005)

Takahashi M, Hayashi M, Manganaro T \& Donahoe P 1986 The ontogeny of mullerian inhibiting substance in granulosa-cells of the bovine ovarian follicle. Biology of Reproduction 35 447-453. (doi:10.1095/ biolreprod35.2.447)

Taneja M, Bols PE, Van de Velde A, Ju JC, Schreiber D, Tripp MW, Levine H, Echelard Y, Riesen J \& Yang X 2000 Developmental competence of juvenile calf oocytes in vitro and in vivo: influence of donor animal variation and repeated gonadotropin stimulation. Biology of Reproduction 62 206-213. (doi:10.1095/biolreprod62.1.206)

Torres-Rovira L, Gonzalez-Bulnes A, Succu S, Spezzigu A, Manca ME, Leoni GG, Sanna M, Pirino S, Gallus M, Naitana S et al. 2014 Predictive value of antral follicle count and anti-Müllerian hormone for follicle and oocyte developmental competence during the early prepubertal period in a sheep model. Reproduction Fertility and Development 26 1094-1106. (doi:10.1071/RD13190)

Torres-Rovira L, Succu S, Pasciu V, Manca ME, Gonzalez-Bulnes A, Leoni GG, Pennino MG, Spezzigu A, Gallus M, Dattena M et al. 2016 Postnatal pituitary and follicular activation: a revisited hypothesis in a sheep model. Reproduction 151 215-225. (doi:10.1530/REP-150316)

Tsoulis MW, Chang PE, Moore CJ, Chan KA, Gohir W, Petrik JJ, Vickers MH, Connor KL \& Sloboda DM 2016 Maternal high-fat diet-induced loss of fetal oocytes is associated with compromised follicle growth in adult rat offspring. Biology of Reproduction 94 94. (doi:10.1095/ biolreprod.115.135004)

Ueno S, Kuroda T, Maclaughlin DT, Ragin RC, Manganaro TF \& Donahoe PK 1989 Mullerian inhibiting substance in the adult rat ovary during various stages of the estrous cycle. Endocrinology 125 1060-1066. (doi:10.1210/endo-125-2-1060)

Veiga-Lopez A, Ye W \& Padmanabhan V 2012 Developmental programming: prenatal testosterone excess disrupts anti-Müllerian hormone expression in preantral and antral follicles. Fertility and Sterility 97 748-756. (doi:10.1016/j.fertnstert.2011.12.028)

Vernunft A, Schwerhoff M, Viergutz T, Diederich M \& Kuwer A 2015 Anti-Muellerian hormone levels in plasma of Holstein-Friesian heifers as a predictive parameter for ovum pick-up and embryo production outcomes. Journal of Reproduction and Development 61 74-79. (doi:10.1262/jrd.2014-091)

Vigier B, Picard JY, Tran D, Legeai L \& Josso N 1984 Production of antiMüllerian hormone: another homology between Sertoli and granulosa cells. Endocrinology 114 1315-1320. (doi:10.1210/endo-114-4-1315) 
Walsh SW, Mossa F, Butler ST, Berry DP, Scheetz D, Jimenez-Krassel F, Tempelman RJ, Carter F, Lonergan P, Evans AC et al. 2014 Heritability and impact of environmental effects during pregnancy on antral follicle count in cattle. Journal of Dairy Science 97 4503-4511. (doi:10.3168/ jds.2013-7758)

Weenen C, Laven JS, Von Bergh AR, Cranfield M, Groome NP, Visser JA, Kramer P, Fauser BC \& Themmen AP 2004 Anti-Müllerian hormone expression pattern in the human ovary: potential implications for initial and cyclic follicle recruitment. Molecular Human Reproduction 10 77-83. (doi:10.1093/molehr/gah015)

Weller MM, Fortes MR, Marcondes MI, Rotta PP, Gionbeli TR, Valadares Filho SC, Campos MM, Silva FF, Silva W, Moore S et al. 2016 Effect of maternal nutrition and days of gestation on pituitary gland and gonadal gene expression in cattle. Journal of Dairy Science 99 3056-3071. (doi:10.3168/jds.2015-9673)

Received 21 February 2017

First decision 14 March 2017

Revised manuscript received 20 March 2017

Accepted 28 March 2017 